\title{
The Influence of Oil Prices on Stock Market Returns: Empirical Evidence from Oil Exporting and Oil Importing Countries
}

\author{
Dimitrios Asteriou ${ }^{1,2}$, Augustinos Dimitras ${ }^{1} \&$ Andrea Lendewig $^{3}$ \\ ${ }^{1}$ School of Social Sciences, Hellenic Open University, Greece \\ ${ }^{2}$ School of Social Sciences, Open University of Cyprus, Cyprus \\ ${ }^{3}$ School of Social Sciences, City University, UK \\ Correspondence: Dimitrios Asteriou, School of Social Sciences, Hellenic Open University, Bouboulinas 57-59, \\ Patras, 26222, Greece. Tel: 30-94-710-0540. E-mail: d.a.asteriou@eap.gr
}

Received: April 24, 2013

Accepted: July 4, 2013

Online Published: August 23, 2013

doi:10.5539/ijbm.v8n18p101

URL: http://dx.doi.org/10.5539/ijbm.v8n18p101

\begin{abstract}
The aim of this paper is to study the impact of oil price fluctuations on the stock markets and the interest rates from oil importing and oil exporting countries. To this end, Vector Autoregressive (VAR) models are estimated and pairwise Granger Causality tests are performed to the stationary series in order to analyse the short-term relationships among the variables. Also, the Johansen approach for multiple equations is carried out in order to test for cointegration among the series. Finally, the existence of cointegration set the estimation of Vector Error-Correction Models (VECMs) to investigate the long-term links between the financial variables and the oil prices. The major findings of this paper include: first, the interaction between the oil prices and the stock markets is much stronger than with the interest rates in the short and in the long-run. Second, the impact on oil importing countries is more significant than on oil exporting countries. Finally, it might be possible that the fluctuations in oil prices have different effects on developed and developing countries.
\end{abstract}

Keywords: oil prices, vector error correction models, causality

\section{Introduction}

Oil is one of the most important sources of energy in the world at present. On the other hand, equities are priced depending upon the market valuation according to the firms' performances and based on the expected profits. In other words, equity prices are the estimation of the profitability expected from an organization. Thus, since oil might represent a significant input in the companies' production processes (directly or indirectly) boosting the production costs (when the price increases) and therefore decreasing the profits, oil price risks might be also priced in the stock markets. Hence, there may be an important influence from oil shocks on the stock market that allows the forecast of equity prices, due to the fact that, even if oil is a significant input or an output in the organization, changes in its price will affect profits. Therefore, decreases and increases in oil prices may be used to predict increases and decreases in equity prices.

Despite the fact that, based on previous research, oil price changes seem to affect equity prices in a negative manner, a deeper analysis should be done as regard the different impacts on oil exporting and on oil importing countries. In the OPEC countries and in other oil exporter countries the effect of increases in oil prices should be positive, whereas for the oil importing countries the impact should be negative.

On the other hand, the interest rates are defined as the price of money, and so they are determined by the supply and demand for money. Thus, since the interest rates are the price borrowers have to pay to the lenders when asking for a credit, changes in the interest rates have a major influence on the corporate profits, affecting the price of equities. The interest rates are also used to discount future values to find their present value. Therefore, it was considered important to include the rates of interest into our analysis, since the equity prices are mainly determined by the excepted cash flow stream and the discount rates.

The majority of the relevant papers that are related to this topic concentrate their investigations on developed countries, mainly on the United States, Canada, Japan, Australia, and on European countries, most of which are oil importers. Very few are the studies that have been carried out in developing and oil exporting countries. This study aims to fill this gap by including a complete range of countries in the analysis. The analysis includes a set 
of 31 countries that are divided in two main groups: oil importing and oil exporting countries, some of which are members of the Organization of the Petroleum Exporting Countries (OPEC). The frequency of the data is monthly and the sample period covers 21 years starting in January 1988 and finishing in December 2008. We excluded from the analysis the years after the word economic crisis after 2008 in order to avoid the consequences of the crisis in our results. At the end, it is expected to find differences in the impact from oil price fluctuations on oil importing countries and on oil exporting countries. More specifically, it is expected to find a negative and more significant influence on the oil importers and a positive and weaker effect on the oil exporters. Also it is possible that the results will show a stronger relationship between the oil prices and the stock markets than the link that might exist among the interest rates and the oil prices.

The rest of the paper is organized as follows: section 2 contains a literature review of some of the most relevant studies related to the topic. Section 3 presents the data and the empirical methodology utilized. Section 4 discusses the empirical results, while section 5 concludes.

\section{Literature Review}

There are many researchers that have studied the impact of oil price fluctuations on the economy. Hamilton (1983) argues that increases in oil prices are a contributing factor in almost every US recession in the post World War II period and prior to 1972 and Mork (1989) extended these results, providing evidence of asymmetric effects of oil price shifts on the economy, namely a strongly negative effect of oil price increases and no significant effect of oil price decreases. However, there are relatively few papers that analysed the effect of oil shocks on the stock market.

Some of the former studies concluded that rises in oil prices have a negative impact on real stock returns (e.g. Jones \& Kaul, 1996; Sadorsky, 1999, Garefalakis et al., 2011). On the other hand, Huang et al. (1996), found that there is no correlation between oil futures returns and stock market returns in the US. But, there is evidence that oil prices influence the stock prices of different sectors (Sawyer \& Nandha, 2006; Sadorsky, 2001; El-Sharif et al., 2005; Nandha \& Faff, 2008; Henriques \& Sadorsky, 2008).

Furthermore, oil shocks seem to be priced in stock markets as it might represent a significant input or output of the company. Apparently, when oil is a direct or indirect input in the organizations' production process, there is a negative effect of oil price increases since they boost the production costs. Nonetheless, when oil is an output of the organization, its price increments seem to have a positive effect on stock returns, due to profit increases (c.f. Faff \& Brailsford, 1999; Boyer \& Filion, 2007; Cameron \& Schnusenberg, 2009).

In the same way, oil price fluctuations seem to have different impacts on the oil importing and oil exporting countries' stock market. Many papers have been focused on studying the influence of oil price movements on oil importer stock markets. Both the studies by Sadorsky (1999) and Cobo-Reyes and Pérez Quirós (2005), concluded that increases in oil prices have a negative effect on the S\&P 500 stock index. Odusami (2009) showed that returns on crude oil futures have a negative impact on the US stock market returns. Similar results provide Faff and Brailsford (1999) for Australia, Papapetrou (2001) and Hondroyiannis and Papapetrou (2001) for Greeceas well as Huang \& Guo (2008) for Japan. But Cong et al. (2008) documented that oil price shocks have not a statistically significant impact on the stock market indices in China, with the exception of the manufacturing index and some oil companies. On the other hand, analyses that take into account oil exporting countries include those by Bjømland (2008) who found that stock returns in Norway respond positively to oil price shocks, by Hayo and Kutan (2005) that argued that oil price fluctuations destabilize the Russian stock market, by Onour (2007) showing that oil price changes have long-term effects on the stock market returns of the Gulf Cooperation Council (GCC) countries and by Hammoudeh and Aleisa (2004) that indicate a direct link between the equity index and the oil prices only for the Saudi Arabian stock market in a study focusing on the stock markets of the GCC countries, excluding Qatar. Other researchers included both, oil importing and oil exporting countries, in their studies. Jones \& Kaul (1996) demonstrate that oil price movements have a negative impact on real stock returns in the US, Canada, Japan, and the UK during the post-war period. Later, Park \& Ratti (2008) documented that oil price shocks have a negative statistically significant impact on real stock returns for the US and ten European countries. Also, Hammoudeh \& Li (2005) concluded that increases in oil prices lead the stock returns of Mexico and Norway, both oil exporting countries, and the US oil-sensitive industry, but decreases the US transportation industry stock returns. Most recently, Apergis \& Miller (2009), in their investigation of the influence of structural oil-market shocks on stock prices in a sample of eight countries, including both oil importing and oil exporting countries, exposed that oil-market structural shocks hardly explain stock market return changes. 
Table 1. Descriptive statistics, monthly data (Jan 1988-Dec 2008)

\begin{tabular}{|c|c|c|c|c|c|c|c|c|c|c|c|c|c|c|c|}
\hline & \multicolumn{6}{|c|}{ Share Prices } & \multicolumn{3}{|c|}{ Correlations } & \multicolumn{5}{|c|}{ Interest Rates } & \multirow[b]{2}{*}{ Obs } \\
\hline & Mean & Max & Min & St. Dev. & Skew & Kurt & Obs & with oil pr & Mean & Max & Min & St. Dev. & Skew & Kurt & \\
\hline Australia & 379.27 & 1127.44 & 154.18 & 205.39 & 1.70 & 5.08 & 252 & 0.74 & 7.76 & 17.91 & 4.14 & 3.84 & 1.27 & 3.33 & 174 \\
\hline Belgium & 1086.44 & 2436.59 & 392.11 & 502.59 & 0.91 & 2.96 & 252 & 0.27 & 4.88 & 10.52 & 1.89 & 2.61 & 0.79 & 2.19 & 252 \\
\hline Brazil & 876.82 & 4627.27 & 84.09 & 880.67 & 2.24 & 7.87 & 252 & 0.84 & 21.77 & 84.57 & 10.50 & 10.43 & 2.68 & 12.75 & 157 \\
\hline Canada & 704.30 & 2081.50 & 284.64 & 447.47 & 1.42 & 4.09 & 252 & 0.81 & 5.43 & 13.67 & 0.95 & 3.04 & 1.15 & 3.43 & 252 \\
\hline China & 47.69 & 132.40 & 13.63 & 27.48 & 0.66 & 2.43 & 192 & 0.81 & 5.73 & 10.44 & 2.70 & 2.86 & 0.41 & 1.51 & 226 \\
\hline Finland & 355.78 & 1235.87 & 38.46 & 294.64 & 0.95 & 3.08 & 252 & 0.82 & 7.06 & 13.74 & 3.05 & 3.23 & 0.65 & 1.92 & 252 \\
\hline France & 1025.54 & 2312.51 & 254.76 & 526.58 & 0.69 & 2.54 & 252 & 0.58 & 5.26 & 11.80 & 1.93 & 2.90 & 0.72 & 2.09 & 252 \\
\hline Germany & 1052.54 & 2520.74 & 319.94 & 511.81 & 0.82 & 3.07 & 252 & 0.71 & 4.36 & 8.75 & 1.65 & 2.05 & 0.84 & 2.51 & 236 \\
\hline Greece & 394.80 & 1036.08 & 85.42 & 231.91 & 0.90 & 2.87 & 252 & 0.70 & 11.41 & 25.50 & 2.01 & 7.73 & 0.27 & 1.51 & 252 \\
\hline India & 176.02 & 669.95 & 73.97 & 126.14 & 1.97 & 6.26 & 192 & 0.79 & 8.87 & 12.00 & 6.00 & 2.42 & 0.06 & 1.41 & 252 \\
\hline Italy & 333.40 & 684.27 & 138.27 & 139.88 & 0.73 & 2.46 & 252 & 0.44 & 6.92 & 17.98 & 1.90 & 4.16 & 0.43 & 1.72 & 252 \\
\hline Japan & 2789.34 & 4149.23 & 1459.96 & 625.55 & -0.05 & 2.35 & 252 & 0.10 & 1.28 & 5.55 & 0.00 & 1.67 & 1.36 & 3.65 & 252 \\
\hline Kazakhstan & 833.29 & 1101.74 & 278.90 & 223.59 & -0.78 & 2.40 & 37 & 0.42 & 29.91 & 318.78 & 3.28 & 63.17 & 3.26 & 12.79 & 171 \\
\hline Korea & 169.27 & 488.20 & 35.08 & 87.67 & 1.45 & 4.89 & 252 & 0.81 & 9.87 & 17.00 & 3.53 & 4.07 & 0.11 & 1.62 & 252 \\
\hline Kuwait & 1003.85 & 1370.57 & 722.04 & 197.90 & 0.33 & 1.56 & 43 & 0.66 & 5.96 & 8.87 & 0.60 & 2.17 & -0.81 & 2.48 & 182 \\
\hline Malaysia & 229.31 & 453.86 & 55.27 & 93.49 & 0.65 & 2.34 & 252 & 0.66 & 4.51 & 9.98 & 1.74 & 1.84 & 0.51 & 1.94 & 252 \\
\hline Mexico & 1884.51 & 6691.25 & 100.00 & 1589.18 & 1.58 & 4.71 & 252 & 0.50 & 20.81 & 157.07 & 4.45 & 19.16 & 3.43 & 21.55 & 252 \\
\hline Netherlands & 1438.01 & 3018.02 & 433.06 & 688.69 & 0.24 & 2.03 & 252 & 0.64 & 5.70 & 9.19 & 3.12 & 1.63 & 0.52 & 2.23 & 252 \\
\hline Nigeria & 482.49 & 1134.57 & 157.94 & 288.20 & 0.83 & 2.36 & 79 & 0.68 & 13.97 & 27.50 & 2.15 & 4.81 & 0.24 & 3.28 & 210 \\
\hline Norway & 1400.18 & 4581.03 & 446.70 & 942.58 & 1.86 & 5.52 & 252 & 0.74 & 6.67 & 13.64 & 2.97 & 2.67 & 0.85 & 2.74 & 252 \\
\hline Oman & 1068.04 & 1652.11 & 802.10 & 243.09 & 0.96 & 2.79 & 43 & 0.68 & 6.22 & 8.50 & 0.50 & 2.33 & -1.47 & 3.61 & 252 \\
\hline Qatar & 792.84 & 1147.66 & 498.64 & 194.16 & 0.25 & 1.87 & 43 & 0.27 & 3.65 & 5.50 & 1.33 & 1.77 & -0.15 & 1.25 & 79 \\
\hline Russia & 462.27 & 1599.85 & 32.92 & 412.24 & 1.18 & 3.12 & 168 & 0.70 & 41.67 & 355.80 & 2.20 & 60.22 & 2.68 & 11.31 & 104 \\
\hline SaudiA. & 680.62 & 1234.96 & 412.69 & 240.11 & 0.82 & 2.47 & 37 & -0.21 & 4.23 & 7.05 & 1.11 & 1.81 & -0.19 & 1.62 & 144 \\
\hline Singapore & 2025.75 & 4574.92 & 729.35 & 795.11 & 0.93 & 3.68 & 252 & 0.63 & 1.98 & 5.45 & 0.35 & 1.18 & 0.66 & 2.51 & 252 \\
\hline Spain & 309.50 & 890.16 & 102.73 & 193.23 & 1.17 & 3.65 & 252 & 0.63 & 6.69 & 14.49 & 1.84 & 4.13 & 0.58 & 1.82 & 252 \\
\hline Thailand & 227.43 & 625.24 & 45.07 & 146.71 & 1.08 & 3.28 & 252 & 0.82 & 7.79 & 10.75 & 2.57 & 2.76 & -0.12 & 1.40 & 252 \\
\hline Turkey & 228.78 & 784.30 & 36.16 & 155.00 & 1.28 & 4.10 & 252 & 0.76 & 51.26 & 193.71 & 0.00 & 31.21 & 0.97 & 5.22 & 188 \\
\hline UK & 890.54 & 1707.16 & 364.41 & 344.67 & 0.34 & 2.07 & 252 & 0.55 & 6.63 & 14.59 & 1.30 & 3.02 & 1.34 & 3.76 & 252 \\
\hline US & 814.88 & 1473.78 & 229.41 & 397.77 & -0.01 & 1.49 & 252 & 0.50 & 4.31 & 8.83 & 0.04 & 1.97 & -0.02 & 2.46 & 252 \\
\hline Venezuela & 123.07 & 269.88 & 60.55 & 38.93 & 1.12 & 4.50 & 181 & 0.45 & 29.49 & 84.20 & 5.19 & 16.52 & 1.02 & 3.49 & 228 \\
\hline OilPrices & 30.7 & 132.55 & 10.41 & 22.88 & 2.14 & 7.68 & 252 & & & & & & & & \\
\hline
\end{tabular}

Table 2. Unit root tests on levels and first differences

\begin{tabular}{|c|c|c|c|c|c|c|c|c|c|c|c|c|}
\hline & \multicolumn{6}{|c|}{ UNIT ROOT TEST - LEVELS } & \multicolumn{6}{|c|}{ UNIT ROOT TESTS - FIRST DIFFERENCES } \\
\hline & \multicolumn{3}{|c|}{ Share Prices } & \multicolumn{3}{|c|}{ Interest Rates } & \multicolumn{3}{|c|}{ Share Prices } & \multicolumn{3}{|c|}{ Interest Rates } \\
\hline & Trend & Trend \& & None & Trend & Trend \& Con & None & Trend & Trend \& & None & Trend & Trend \& & None \\
\hline & & Con & & & & & \multicolumn{3}{|c|}{ Con } & \multicolumn{3}{|c|}{ Con } \\
\hline Australia & -0.883 & -1.331 & -1.156 & -1.616 & -1.876 & -0.383 & -9.409 & -9.377 & -9.379 & -11.402 & -11.398 & -11.413 \\
\hline Belgium & -1.102 & -2.486 & -1.077 & -1.639 & -0.835 & -0.598 & -11.214 & -11.204 & -11.210 & -11.760 & -11.867 & -11.785 \\
\hline Brazil & -3.267 & -4.131 & -2.290 & -2.083 & -2.721 & -0.930 & - & - & - & -11.711 & -11.686 & -11.723 \\
\hline Canada & -1.037 & -2.089 & -1.457 & -1.482 & -2.211 & -0.380 & -7.936 & -7.922 & -7.861 & -11.140 & -11.119 & -11.148 \\
\hline China & -0.844 & -1.204 & -1.654 & -1.877 & -1.625 & -1.438 & -14.777 & -14.745 & -14.678 & -12.038 & -12.050 & -12.039 \\
\hline Finland & -0.801 & -2.306 & -1.269 & -1.696 & -2.095 & -0.854 & -12.485 & -12.458 & -12.442 & -13.115 & -13.102 & -13.136 \\
\hline France & -1.006 & -2.284 & -1.197 & -1.633 & -1.493 & -0.151 & -12.228 & -12.204 & -12.209 & -13.043 & -13.089 & -13.042 \\
\hline Germany & -1.040 & -2.446 & -0.323 & -1.782 & -1.850 & -0.310 & -8.627 & -8.652 & -8.645 & -12.513 & -12.537 & -12.521 \\
\hline Greece & -0.583 & -1.328 & -1.889 & -1.727 & -1.520 & -0.592 & -20.674 & -20.632 & -20.483 & -14.577 & -14.600 & -14.600 \\
\hline India & -0.402 & -1.911 & -1.124 & -1.625 & -1.963 & -0.749 & -10.815 & -10.847 & -10.740 & -10.623 & -10.596 & -10.648 \\
\hline Italy & -0.945 & -1.957 & -1.569 & -1.340 & -0.926 & -0.323 & -15.840 & -15.808 & -15.795 & -13.797 & -13.832 & -13.822 \\
\hline Japan & -0.792 & -1.054 & -1.121 & -2.158 & -2.508 & -0.829 & -4.401 & -4.390 & -4.379 & -15.079 & -15.053 & -15.100 \\
\hline
\end{tabular}




\begin{tabular}{|c|c|c|c|c|c|c|c|c|c|c|c|c|}
\hline Kazakhstan & -8.554 & -8.920 & -7.157 & -1.378 & -0.957 & -0.539 & - & - & - & -5.196 & -5.709 & -5.289 \\
\hline Korea & -1.184 & -3.666 & -1.046 & -1.982 & -2.033 & -0.896 & -12.079 & - & -12.076 & -7.903 & -7.888 & -7.926 \\
\hline Kuwait & -0.225 & -3.252 & -0.580 & -1.616 & -0.821 & -0.317 & -11.460 & -11.656 & -11.476 & -4.200 & -4.467 & -4.256 \\
\hline Malaysia & -2.048 & -3.216 & -0.809 & -2.595 & -2.502 & -0.776 & -11.713 & -11.718 & -11.736 & -7.794 & -7.810 & -7.808 \\
\hline Mexico & -8.993 & -10.934 & -6.230 & -1.704 & -2.150 & -0.806 & - & - & - & -6.710 & -6.681 & -6.727 \\
\hline Netherlands & -0.895 & -3.115 & -0.862 & -1.555 & -0.717 & -0.182 & -10.833 & -10.846 & -10.827 & -14.582 & -14.661 & -14.596 \\
\hline Nigeria & -2.516 & -3.170 & -1.299 & -1.349 & -1.310 & -0.315 & -10.677 & -10.655 & -10.685 & -5.713 & -5.768 & -5.728 \\
\hline Norway & -2.363 & -2.535 & -2.826 & -4.009 & -4.105 & -2.653 & -13.795 & -13.836 & - & - & - & - \\
\hline Oman & -1.324 & -2.561 & -1.273 & -2.687 & -2.820 & -1.078 & -22.015 & -21.995 & -22.008 & $(*)-1.751$ & $\left({ }^{*}\right)-1.745$ & $(*)-1.752$ \\
\hline Qatar & -0.971 & -2.009 & 0.434 & -1.133 & -1.190 & -0.704 & $\left({ }^{*}\right)-2.211$ & $\left({ }^{*}\right)-2.173$ & -1.954 & -5.544 & -5.469 & -5.547 \\
\hline Russia & -1.790 & -2.123 & -1.793 & -1.490 & -1.855 & -0.794 & -3.335 & $(*)-3.297$ & -3.439 & -9.615 & -9.632 & -9.640 \\
\hline SaudiA. & -1.394 & -1.748 & -1.088 & -1.044 & -1.561 & -0.718 & -7.090 & -7.045 & -7.090 & -4.954 & -4.884 & -4.991 \\
\hline Singapore & -3.471 & -3.928 & -1.613 & -2.095 & -1.965 & -0.240 & - & - & -10.014 & -13.526 & -13.550 & -13.544 \\
\hline Spain & -1.033 & -2.252 & -1.488 & -1.318 & -2.092 & -0.229 & -8.266 & -8.248 & -8.188 & -12.255 & -12.235 & -12.261 \\
\hline Thailand & -0.569 & -2.501 & -0.849 & -1.374 & -1.849 & -0.718 & -12.611 & -12.702 & -12.606 & -8.884 & -8.908 & -8.903 \\
\hline Turkey & -2.299 & -2.779 & -1.463 & -2.217 & -2.701 & -1.062 & -3.723 & -3.716 & -3.729 & -15.543 & -15.516 & -15.573 \\
\hline UK & -0.880 & -2.133 & -1.267 & -1.582 & -0.646 & -0.200 & -8.930 & -8.946 & -8.880 & -12.708 & -12.812 & -12.724 \\
\hline US & -1.474 & -2.527 & -1.383 & -1.475 & 0.170 & 0.125 & -4.713 & -4.750 & -4.648 & -13.257 & -13.381 & -13.255 \\
\hline Venezuela & -3.633 & -3.767 & -1.414 & -2.933 & -3.007 & -0.602 & - & - & -16.913 & - & -15.353 & -15.430 \\
\hline Oilprice & -2.581 & -3.473 & -1.460 & & & & -8.054 & - & -8.073 & & & \\
\hline
\end{tabular}

Note: the numbers in bold denote that the series are stationary at the $5 \%$ level of significance. Thecritical values of $-2.88,-3.45$ and -1.94 for the intercept, trend and intercept and none respectively, were taken from Fuller (1976). The lag lengths were based on the Sch warz Information Criterion.

(*)Became stationary after taking second differences.

Examining the symmetric effect of the impact of oil price changes on the stock market, Nandha \& Faff (2008) state that the impact of oil price movements on equity prices is symmetric, Cong et al. (2008) concluded that there was no statistical evidence to support the asymmetric effect of oil price changes on stock returns for Chinese oil companies, though little evidence of asymmetric effects for oil importing European countries was found by Park \& Ratti (2008). Additionally, according to Guidi et al. (2006) the UK and the US have asymmetric reactions to OPEC policy decisions during conflict periods and non-conflict periods; nonetheless, Odusami (2009) reported a not significant impact on the US stock market from OPEC meetings.

With regard to the long-run relationship between oil price shocks and the stock market, Hammoudeh et al. (2004) and Lescaroux \& Mignon (2008) argued that there is a long-run relationship between oil prices and the stock market and Miller \& Ratti (2009) state the same for specific time intervals. When it comes to the relationship between oil price volatility and the stock market, Huang et al.(1996) confirmed a link between oil futures volatility and stock market volatility, Huang et al. (2005) found evidence of the effect that oil price volatility has on stock returns for Canada, Malik and Hammoudeh (2007) reported the Bahrain, Kuwait and Saudi Arabia equity markets receive volatility from the oil market and Aloui and Jammazi (2009) showed the significant role that oil price increases play in determining the volatility of real returns. On the other hand, the influence of oil price volatility found to be insignificant for stock markets of all GCC counties (Onour, 2007), and China (Cong et al., 2008).

\section{The Data and Methodology}

\subsection{The Data Set}

The data used in this study include monthly time series for 31 countries over the 20 years period from January 1988 to December 2008. The set of countries include both oil importing and oil exporting countries, some of which are members of the Organization of the Petroleum Exporting Countries (OPEC). The criteria used to classify the countries in oil importing and oil exporting, was based on the Energy Information Administration website data for 2008. Analytically the sample included 18 oil importing countries (Australia, Belgium, China, Finland, France, Germany, Greece, India, Italy, Japan, Korea, the Netherlands, Singapore, Spain, Thailand, Turkey, the United Kingdom, the United States) and 13 oil exporting countries from which 5 are members of OPEC (Kuwait, Nigeria, Saudi Arabia, Qatar, Venezuela) and the rest of them are: Brazil, Canada, Kazakhstan, Malaysia, Mexico, Norway, Oman, Russia. The data series do not extend beyond 2008 as the financial crisis and its different consequences in the various countries could affect the results. Although the study of the relation 
between oil prices, stock markets and interest rates can be very interesting, the financial turmoil of the post 2008 period and the different impact on the countries could lead in false indications and conclusions.

Three variables (stock market, interest rates and oil prices) were used to carry out the present analysis. As a proxy for the stock market, the Morgan Stanley Capital International Index (MSCI) in US dollars, proposed by Hammoudeh and Li (2005), was applied. Different proxies were employed for the interest rates due to issues in the availability of the data. The Treasury Bill Rate was used for most of the countries with the exception of Finland, Korea, the Netherlands, Norway, Thailand, and Venezuela where the long-term Government Bond Yield was applied; China, India, Oman, and Qatar where the Discount Rate was implemented; and finally the Deposit Rate for Saudi Arabia. In the case of the oil price the Petroleum: Average Crude Price expressed in US dollar per Barrel was found to be the most suitable for the purposes of this study. All the above data were acquired from DataStream.

The average crude oil price was sourced from the International Monetary Fund (IMF) International Financial Statistics (IFS) data via the Economic and Social Data Service (ESDS) website. It is also worth noting that there are some observations missing for the time series of some countries, especially in the case of the developing countries.

In order to examine the behaviour of the data a descriptive statistics analysis was carried out. From the results presented in Table 1, we see that on average China has the lowest MSCI index (US\$ 47.69) whereas Japan has the highest (US\$ 2,789.34). Interestingly, the countries do not seem to follow a specific pattern as regard the MSCI index. The analysis of the median value supports this conclusion, as the minimum median of the MSCI index of US\$ 13.63 is found for China and the maximum MSCI index of US\$ 6,691.25 is found for Mexico. However, China records the lowest standard deviation at US\$ 27.48 whereas Mexico records the highest at US\$ 1,589.18. Regarding the shape of the distributions of the MSCI indices, Kazakhstan displays the most negative coefficient of skewness (-0.7788) which implies a left-skewed distribution, by contrast, most of the countries display a right-skewed distribution being Brazil the country with the most positive coefficient of skewness (2.2374). Moreover, half of the countries have a kurtosis less than three, meaning that the distribution of the data is flat and spread out (platykurtic), whereas the peakedness of the distribution of the data of the other countries is high and thin (leptokurtic). In the case of the correlations with the oil prices, it can be seen that, with the exception of Saudi Arabia which displays a weak negative correlation (-0.21), all the MSCI indices are positively correlated with the oil prices. Furthermore, Korea, Canada, China, Thailand, Finland, and Brazil present a relatively strong positive relationship with the oil prices (over 0.80 ), whereas the remaining countries report a weak to moderate positive correlation.

Regarding interest rates, Japan presents the lowest median $(0.37 \%)$ and average percentage $(1.28 \%)$, whereas Turkey presents the highest $(50.14 \%$ and $51.26 \%$ respectively). It is also important to note that the highest average rates, medians, maximums and standard deviations are reported by developing countries, such as Nigeria, Mexico, Brazil, Venezuela, Kazakhstan, Russia, and as mention before Turkey; whereas the lowest correspond to Japan and Singapore (developed countries). On the other hand, Japan as well as Turkey, display the minimum monthly rates of the sample period. In addition, regarding the degree of asymmetry of the interest rates distributions, only six countries can be said are skewed to the left and the remaining are positively skewed. With respect to the peakedness of the distributions, most of the countries present a platykurtic distribution.

In the case of the oil prices, the results suggest that the average monthly price of the sample period was US\$ 30.70 per Barrel with quite a high standard deviation of US\$22.88. During the 21 years period the commodity reached a peak of US\$ 132.55 and dropped to US\$ 10.41 . The distribution of the data of this time series has a high and thin shape and is positively skewed.

\subsection{Methodology}

In studying the impact of oil price shocks on stock market returns, the Vector Autoregressive (VAR) model has been widely used. Such are the cases of Sadorsky (1999), Papapetrou (2001), Maghyereh (2004), Bjømland (2008), Park and Ratti (2008), Henriques and Sadorsky (2008), Lescaroux and Mignon (2008), and Cong et al. (2008) among others. Some of which also apply Causality tests in order to define the relationship among the variables.

In this empirical analysis VAR models were performed in order to study the behaviour of the oil prices and capture its relationships with the stock markets and the interest rates. According to Sims (1980), all variables can be treated as endogenous if there is simultaneity among them. Thus, since in this case the links between the oil prices with the stock markets and the interest rates are not clear, te variables should be treated symmetrically. Therefore, the following VAR models were created: 


$$
\begin{gathered}
O I L_{t}=a_{1}+\sum_{j=1}^{12} \beta_{j} R_{i, t-j}+\sum_{j=1}^{12} \gamma_{j} O I L_{t-j}+e_{I i t} \\
P_{i, t}=a_{2}+\sum_{j=1}^{12} \theta_{j} P_{i, t-j}+\sum_{j=1}^{12} \delta_{j} P_{t-j}+e_{2 i t} \\
O I L_{t}=a_{1}^{\prime}+\sum_{j=1}^{12} \beta_{j}^{\prime} I R_{i, t-j}+\sum_{j=1}^{12} \gamma_{j}^{\prime} O I L_{t-j}+\varepsilon_{l i t} \\
I R_{i, t}=a_{2}^{\prime}+\sum_{j=1}^{12} \theta_{j}^{\prime} I R_{i, t-j}+\sum_{j=1}^{12} \delta_{j}^{\prime} O I L_{t-j}+\varepsilon_{l i t}
\end{gathered}
$$

where the time series of the oil prices (OIL) are affected by past values (12 lags) of the stock market indices (P) and of the interest rates (IR) respectively, and, simultaneously, the time series of each stock market index and the interest rate from each country are affected by past values (12 lags) of the oil prices.

In order to test for the significance of the coefficients of the estimated VAR models, statistical inference is normally used. For the effects of this study such inference was carried out by applying the standard Granger Causality tests (Granger, 1969). However, due to the fact that it is required for the variables to be stationary before testing for causality, the Augmented Dickey-Fuller (ADF) test for unit roots was performed. Since the Granger test results show only short-run relationships among the variables, we then proceed with cointegration tests and the estimation of Vector Error-Correction Models (VECM) in order to further examine the long-run behaviour of the variables. For the cointegration tests we use the Johansen method applying the Pantula Principle in order to choose the appropriate model.

The VECM has the advantage to combine the short-run and the long-run properties. Thus, when the variables are found to be cointegrated the relationship among them is expressed as a VECM in the following way:

$$
\begin{aligned}
& \Delta O I L_{t}=\alpha_{1}+\sum_{j=1}^{12} \beta_{1 j} I R_{i, t-j}+\sum_{j=1}^{12} \gamma_{1 j} \Delta O I L_{t-j}+\sum_{j=1}^{12} \theta_{1 j} \Delta P_{i, t-j}-\pi_{l} e c m_{i, t-1}+w_{I i t} \\
& \Delta P_{i, t}=\alpha_{2}+\sum_{j=1}^{12} \beta_{2 j} \Delta I R_{i, t-j}+\sum_{j=1}^{12} \gamma_{2 j} \Delta O I L_{t-j}+\sum_{j=1}^{12} \theta_{2 j} \Delta P_{i, t-j}-\pi_{2} e c m_{i, t-1}+w_{2 i t} \\
& \Delta I R_{i, t}=\alpha_{3}+\sum_{j=1}^{12} \beta_{3 j} \Delta I R_{i, t-j}+\sum_{j=1}^{12} \gamma_{3 j} \Delta O I L_{t-j}+\sum_{j=1}^{12} \theta_{3 j} \Delta P_{i, t-j}-\pi_{3} e c m_{i, t-1}+w_{3 i t}
\end{aligned}
$$

Where $\beta_{\mathrm{j}}, \gamma_{\mathrm{j}}$ and $\theta_{\mathrm{j}}$ are the short-run effects; $\pi$ is the feedback effect; and the long-run response is implied in $\mathrm{ecm}_{\mathrm{i}, \mathrm{t}}$, which was estimated by long run equilibrium relationship.

Then redundant variable coefficient tests of the lagged independent variables and of the cointegrating equation term were necessary in order to define their ability to cause and predict the dependent variable in the long run. Since these tests are equivalent to that of the pairwise Granger Causality performed in the levels, we call them long-run Granger causality tests.

\section{Empirical Results}

The main focus of the present investigation is to examine the impact of oil price fluctuations on the stock markets and the interest rates in all the countries under study. The VAR models estimated to be used in the analysis included the three variables (oil prices, stock markets and interest rates). Before proceeding with the pairwise Granger Causality tests, it was necessary to first determine the order of integration of each variable from each country by applying the ADF Test for Unit Roots. And subsequently, make them stationary by calculating the first or second differences, as required.

The ADF test for unit roots was carried out for the three variables and for each country analysed in the present study. The tests were performed in levels and first differences, and in the three different forms (intercept, trend and intercept, and none). The lag lengths chosen for the procedure were selected using the Schwarz Information Criterion. The null hypothesis for the ADF Test for Unit Roots is that the variable has a unit root, in other words the series is non-stationary, against the alternative that the series is stationary. The critical values used in the analysis were taken from Fuller (1976) and are as follows: $-2.88,-3.45$ and -1.94 for the intercept, trend and intercept and none respectively, all of them at the $5 \%$ level of significance.

Table 2 presents the results of the ADF test for unit roots for all the variables and for the three alternative models. The results indicate that the interest rates from Brazil, Kazakhstan, and Mexico are stationary at levels for the three different models. In addition, the interest rates from Singapore and Venezuela reject the null hypothesis of non-stationarity at the 5\% level of significance for the cases of intercept and trend and intercept. Furthermore, Korea and Norway seem to be stationary at the levels in the cases of trend and intercept and none, respectively. The interest rates from the rest of the countries and the models were found to be stationary after first-differencing them, with the exception of Qatar and Russia which became stationary after taking second differences in the cases of intercept and trend and intercept for Qatar and trend and intercept for Russia.

The results shown in Table 2 also suggest that first-differencing the stock market series from most of the countries, removes the non-stationary component. Only in the case of Norway the stock market series is stationary at levels for all the alternative models. Nonetheless, the stock market from Venezuela also presents 
stationarity at levels but just for the intercept model. The exception is Oman whose stock market series became stationary only after taking second differences. The ADF tests also indicate that the oil price series is stationary when the variable is defined in levels for the trend and intercept model, but the intercept and none models contain unit roots. Hence, the latter cases become stationary after taking first differences, meaning that they are integrated of other one, $I(1)$. For this series second differences were not required.

As it was expected the results are not fundamentally different from the results presented by other papers. Given the importance of using stationary variables to carry out the VAR analysis, the following step was to calculate the first differences where series containing a unit root were found. However, for simplicity and in order to achieve homogeneity among the variables from the different countries, first differences were taken for all the series due to the fact that for most countries the variables had a unit root. Hence, from this step the following series were generated: $\Delta \mathrm{OIL}_{\mathrm{t}}, \Delta \mathrm{P}_{\mathrm{i}, \mathrm{t}}$ and $\Delta \mathrm{IR}_{\mathrm{i}, \mathrm{t}}$.

Table 3. Pairwise granger causality tests (12 lags)

\begin{tabular}{|c|c|c|c|c|}
\hline & doil_price $\rightarrow$ dinterest_rate & dinterest_rate $\rightarrow$ doil_price & doil_price $\rightarrow$ dstock_market & dstock_market $\rightarrow$ doi_price \\
\hline \multirow[t]{2}{*}{ Australia } & 0.454 & 0.934 & 4.226 & 5.503 \\
\hline & $(0.938)$ & $(0.515)$ & $(0.000)$ & $(0.000)$ \\
\hline \multirow[t]{2}{*}{ Belgium } & 0.918 & 0.168 & 1.942 & 1.784 \\
\hline & $(0.529)$ & $(0.999)$ & $(0.031)$ & $(0.052)$ \\
\hline \multirow[t]{2}{*}{ Brazil } & 0.218 & 0.236 & 4.574 & 3.325 \\
\hline & $(0.997)$ & $(0.996)$ & $(0.000)$ & $(0.000)$ \\
\hline \multirow{2}{*}{ Canada } & 1.177 & 0.550 & 6.386 & 1.867 \\
\hline & $(0.301)$ & $(0.880)$ & $(0.000)$ & $(0.040)$ \\
\hline \multirow[t]{2}{*}{ China } & 1.203 & 0.560 & 0.661 & 1.564 \\
\hline & $(0.284)$ & $(0.872)$ & $(0.787)$ & $(0.108)$ \\
\hline \multirow[t]{2}{*}{ Finland } & 1.247 & 0.462 & 1.348 & 1.457 \\
\hline & $(0.253)$ & $(0.935)$ & $(0.194)$ & $(0.142)$ \\
\hline \multirow[t]{2}{*}{ France } & 1.110 & 0.252 & 2.364 & 1.754 \\
\hline & $(0.354)$ & $(0.995)$ & $(0.007)$ & $(0.058)$ \\
\hline \multirow[t]{2}{*}{ Germany } & 0.599 & 1.587 & 2.610 & 2.354 \\
\hline & $(0.842)$ & (0.098) & $(0.003)$ & $(0.007)$ \\
\hline \multirow[t]{2}{*}{ Greece } & 0.424 & 0.130 & 2.103 & 2.209 \\
\hline & $(0.953)$ & $(1.000)$ & $(0.018)$ & $(0.012)$ \\
\hline \multirow[t]{2}{*}{ India } & 0.239 & 0.395 & 3.976 & 5.103 \\
\hline & $(0.996)$ & $(0.965)$ & $(0.000)$ & $(0.000)$ \\
\hline \multirow[t]{2}{*}{ Italy } & 0.959 & 0.296 & 1.415 & 1.571 \\
\hline & $(0.489)$ & $(0.990)$ & $(0.160)$ & $(0.102)$ \\
\hline \multirow[t]{2}{*}{ Japan } & 0.469 & 0.343 & 0.737 & 0.789 \\
\hline & $(0.931)$ & $(0.980)$ & $(0.715)$ & $(0.661)$ \\
\hline \multirow[t]{2}{*}{ Kazakhstan } & 0.188 & 0.044 & NA & NA \\
\hline & $(0.999)$ & (1.000) & NA & NA \\
\hline \multirow[t]{2}{*}{ Korea } & 0.641 & 0.302 & 2.911 & 2.692 \\
\hline & $(0.806)$ & (0.989) & $(0.001)$ & $(0.002)$ \\
\hline \multirow[t]{2}{*}{ Kuwait } & 1.005 & 0.643 & 3.223 & 6.250 \\
\hline & $(0.449)$ & $(0.801)$ & $(0.103)$ & $(0.027)$ \\
\hline Malaysia & 0.840 & 0.418 & 0.582 & 1.084 \\
\hline
\end{tabular}




\begin{tabular}{|c|c|c|c|c|}
\hline & $(0.609)$ & $(0.956)$ & $(0.856)$ & $(0.375)$ \\
\hline \multirow[t]{2}{*}{ Mexico } & 0.145 & 0.266 & 2.442 & 2.437 \\
\hline & (1.000) & $(0.994)$ & $(0.005)$ & (0.006) \\
\hline \multirow[t]{2}{*}{ Netherlands } & 1.582 & 0.381 & 2.418 & 1.288 \\
\hline & $(0.098)$ & $(0.969)$ & (0.006) & $(0.227)$ \\
\hline \multirow[t]{2}{*}{ Nigeria } & 0.475 & 1.418 & 2.295 & 0.984 \\
\hline & $(0.927)$ & $(0.162)$ & $(0.024)$ & $(0.480)$ \\
\hline \multirow[t]{2}{*}{ Norway } & 0.906 & 1.070 & 7.070 & 2.991 \\
\hline & $(0.542)$ & $(0.387)$ & $(0.000)$ & $(0.001)$ \\
\hline \multirow[t]{2}{*}{ Oman } & 1.127 & 3.206 & 12.507 & 1.145 \\
\hline & $(0.340)$ & $(0.000)$ & (0.006) & $(0.473)$ \\
\hline \multirow[t]{2}{*}{ Qatar } & 0.378 & 0.179 & 3.454 & 1.303 \\
\hline & $(0.964)$ & (0.999) & $(0.090)$ & $(0.409)$ \\
\hline \multirow[t]{2}{*}{ Russia } & 0.393 & 0.784 & 4.078 & 1.378 \\
\hline & $(0.959)$ & $(0.664)$ & $(0.000)$ & $(0.185)$ \\
\hline \multirow[t]{2}{*}{ SaudiA. } & 1.270 & 1.758 & NA & NA \\
\hline & $(0.247)$ & $(0.064)$ & NA & NA \\
\hline \multirow[t]{2}{*}{ Singapore } & 0.832 & 0.309 & 2.151 & 1.881 \\
\hline & $(0.618)$ & $(0.987)$ & $(0.015)$ & (0.038) \\
\hline \multirow[t]{2}{*}{ Spain } & 1.407 & 0.515 & 2.046 & 2.822 \\
\hline & $(0.164)$ & $(0.904)$ & $(0.022)$ & $(0.001)$ \\
\hline \multirow[t]{2}{*}{ Thailand } & 1.211 & 1.266 & 0.606 & 0.559 \\
\hline & $(0.277)$ & $(0.241)$ & $(0.836)$ & $(0.873)$ \\
\hline \multirow[t]{2}{*}{ Turkey } & 1.579 & 1.127 & 1.865 & 3.224 \\
\hline & $(0.108)$ & $(0.346)$ & $(0.040)$ & $(0.000)$ \\
\hline \multirow[t]{2}{*}{ UK } & 2.731 & 0.557 & 1.947 & 2.003 \\
\hline & $(0.002)$ & $(0.875)$ & $(0.031)$ & $(0.025)$ \\
\hline \multirow[t]{2}{*}{ US } & 2.442 & 1.111 & 1.592 & 0.883 \\
\hline & $(0.005)$ & $(0.352)$ & $(0.095)$ & $(0.565)$ \\
\hline \multirow[t]{2}{*}{ Venezuela } & 0.507 & 0.391 & 1.167 & 1.185 \\
\hline & $(0.908)$ & $(0.965)$ & $(0.312)$ & (0.299) \\
\hline
\end{tabular}

Note: the numbers in bold denote that the series reject the null hypothesis of nocausality at the $10 \%$ level of significance. The critical values used to compare the F-Statistic were calculated in EViews 6.12 were the number of lags included in the procedure. The numbers in parenthesis are the p-values. NA: the number of observations was not enough to perform the test. 
Table 4. Johansen cointegration tests for the three variables (12 lags)

\begin{tabular}{|c|c|c|c|c|c|c|c|c|c|}
\hline Countries & $\begin{array}{c}\text { No of } \\
\text { Cointegrating } \\
\text { vectors (r) }\end{array}$ & Model 2 & Model 3 & Model 4 & Countries & $\begin{array}{c}\text { No of } \\
\text { Cointegrating } \\
\text { Vectors (r) }\end{array}$ & Model & Model 3 & Model \\
\hline \multirow[t]{3}{*}{ Australia } & 0 & 36.51212 & 32.79015 & 50.07611 & Mexico & 0 & 34.71318 & 33.50172 & 43.42367 \\
\hline & 1 & 14.89172 & 12.03919 & 17.80031 & & 1 & 11.90724 & 11.10938 & 19.32648 \\
\hline & 2 & 6.06244 & 4.19214 & 4.79516 & & 2 & 3.46055 & 2.96477 & 5.26960 \\
\hline \multirow[t]{3}{*}{ Belgium } & 0 & 23.49958 & 21.13348 & 35.38904 & Netherlands & 0 & 21.66370 & 20.25414 & 42.94954 \\
\hline & 1 & 6.12779 & 4.03759 & 18.00700 & & 1 & 5.19816 & 4.11594 & 18.77376 \\
\hline & 2 & 2.14708 & 0.15715 & 3.81248 & & 2 & 1.74021 & 0.66726 & 3.39677 \\
\hline \multirow[t]{3}{*}{ Brazil } & 0 & 28.42407 & 27.09459 & 52.51909 & Nigeria & 0 & 60.72222 & 50.50208 & 75.29604 \\
\hline & 1 & 10.80821 & 10.02086 & 19.82811 & & 1 & 25.62222 & 16.99831 & 32.59638 \\
\hline & 2 & 4.71670 & 4.52499 & 5.39525 & & 2 & 10.82909 & 2.66760 & 5.97255 \\
\hline \multirow[t]{3}{*}{ Canada } & 0 & 24.69867 & 20.46229 & 32.72503 & Norway & 0 & 29.02038 & 25.82583 & 41.64326 \\
\hline & 1 & 10.79817 & 6.68642 & 18.45826 & & 1 & 11.99508 & 9.20197 & 15.69432 \\
\hline & 2 & 2.90873 & 0.06258 & 6.30054 & & 2 & 4.81282 & 2.15545 & 5.53749 \\
\hline \multirow[t]{3}{*}{ China } & 0 & 39.72925 & 31.71765 & 49.19626 & Oman & 0 & NA & NA & NA \\
\hline & 1 & 9.74999 & 2.05871 & 14.10128 & & 1 & NA & NA & NA \\
\hline & 2 & 1.74196 & 0.00814 & 2.03051 & & 2 & NA & NA & NA \\
\hline \multirow[t]{3}{*}{ Finland } & 0 & 22.85346 & 18.22167 & 36.17181 & Qatar & 0 & NA & NA & NA \\
\hline & 1 & 6.94001 & 2.99141 & 17.95458 & & 1 & NA & NA & NA \\
\hline & 2 & 2.73332 & 0.25482 & 2.73232 & & 2 & NA & NA & NA \\
\hline \multirow[t]{3}{*}{ France } & 0 & 20.17719 & 16.07783 & 29.45784 & Russia & 0 & 23.84271 & 18.81726 & 29.78046 \\
\hline & 1 & 7.44591 & 3.44477 & 15.48562 & & 1 & 6.29583 & 3.43507 & 10.72338 \\
\hline & 2 & 2.98906 & 0.00461 & 3.18422 & & 2 & 0.53650 & 0.26004 & 1.45632 \\
\hline \multirow[t]{3}{*}{ Germany } & 0 & 18.01291 & 13.75432 & 33.43303 & SaudiA. & 0 & NA & NA & NA \\
\hline & 1 & 7.83245 & 4.86460 & 9.55842 & & 1 & NA & NA & NA \\
\hline & 2 & 2.43915 & 0.76283 & 3.66240 & & 2 & NA & NA & NA \\
\hline \multirow[t]{3}{*}{ Greece } & 0 & 21.54920 & 17.25402 & 34.25557 & Singapore & 0 & 23.26881 & 20.11162 & 34.09939 \\
\hline & 1 & 10.08990 & 6.18268 & 10.64804 & & 1 & 11.19702 & 8.24431 & 19.50467 \\
\hline & 2 & 2.63528 & 2.37574 & 2.87869 & & 2 & 0.79085 & 0.01533 & 7.67309 \\
\hline \multirow[t]{3}{*}{ India } & 0 & 39.65939 & 29.97705 & 51.91240 & Spain & 0 & 28.03200 & 22.95511 & 54.92272 \\
\hline & 1 & 16.79092 & 7.60854 & 16.42106 & & 1 & 9.04304 & 5.10078 & 15.67292 \\
\hline & 2 & 5.32044 & 0.53853 & 2.95375 & & 2 & 3.59178 & 0.78581 & 3.61768 \\
\hline \multirow[t]{3}{*}{ Italy } & 0 & 27.91226 & 25.21231 & 50.49839 & Thailand & 0 & 20.26080 & 17.72127 & 36.28288 \\
\hline & 1 & 8.37283 & 5.67349 & 19.23291 & & 1 & 6.86567 & 4.49866 & 14.84481 \\
\hline & 2 & 2.68777 & 0.15768 & 5.45573 & & 2 & 1.07479 & 0.26486 & 4.23224 \\
\hline \multirow[t]{3}{*}{ Japan } & 0 & 22.96874 & 19.41526 & 49.60811 & Turkey & 0 & 50.86395 & 47.80295 & 55.68653 \\
\hline & 1 & 6.85162 & 3.54600 & 19.11359 & & 1 & 14.07712 & 11.14317 & 16.51099 \\
\hline & 2 & 3.05208 & 0.10878 & 3.32311 & & 2 & 2.69290 & 1.93128 & 6.69514 \\
\hline Kazakhstan & 0 & NA & NA & NA & UK & 0 & 18.54379 & 14.93283 & 24.65345 \\
\hline
\end{tabular}




\begin{tabular}{|c|c|c|c|c|c|c|c|c|c|}
\hline & 1 & NA & NA & NA & & 1 & 8.54229 & 5.30707 & 13.52666 \\
\hline & 2 & NA & NA & NA & & 2 & 2.28670 & 0.36443 & 4.91209 \\
\hline \multirow[t]{3}{*}{ Korea } & 0 & 21.80317 & 18.73257 & 41.61393 & US & 0 & 31.13557 & 25.15136 & 39.46607 \\
\hline & 1 & 9.33084 & 6.66954 & 17.16334 & & 1 & 8.75002 & 4.33514 & 17.19550 \\
\hline & 2 & 2.40436 & 0.82312 & 5.80356 & & 2 & 3.52168 & 0.18011 & 3.65497 \\
\hline \multirow[t]{3}{*}{ Kuwait } & 0 & NA & NA & NA & Venezuela & 0 & 15.91123 & 13.24673 & 25.80210 \\
\hline & 1 & NA & NA & NA & & 1 & 4.32574 & 1.67038 & 11.01117 \\
\hline & 2 & NA & NA & NA & & 2 & 1.18428 & 0.12170 & 1.28850 \\
\hline \multirow[t]{3}{*}{ Malaysia } & 0 & 17.32551 & 15.57500 & 39.80638 & & & & & \\
\hline & 1 & 7.10609 & 5.51800 & 12.21972 & & & & & \\
\hline & 2 & 0.90473 & 0.00502 & 5.01457 & & & & & \\
\hline
\end{tabular}

Note: The number in bold indicates the first time the null cannot be rejected, since the trace statisticis smaller than the $5 \%$ critical value. NA: the number of observations was not enough to perform the test.

Once the series were stationary, we were able to apply the pairwise Granger Causality tests to describe the dynamic of the variables in the short-run. More specifically, the tests were carried out in order to define the short-term links between the oil prices and each financial variable from the 31 countries under study. For the end of this analysis, 12 were the number of lags included in the procedure. To evaluate the null hypothesis of no causality we compare the F-statistics with the F-critical values at the $10 \%$ significance level.

The results are presented in Table 3. From these results it can be seen that in the case of the links between oil prices and interest rates there is no bi-directional causality for any country. Nevertheless, for the Netherlands, the UK and the US, the direction of the causality runs from the oil prices to the interest rates, meaning that past values from the oil prices might cause the interest rates from those oil importing countries. On the other hand, for Germany, Oman and Saudi Arabia the null hypothesis of no causality was rejected at the $10 \%$ level of significance when the direction of the causality was running from the interest rates to the oil prices. So in this case the past values of the interest rates are said to predict the performance of the oil prices. For the rest of the countries the null hypothesis could not be rejected, therefore it was concluded that for those countries the variables are independent.

With regards to the relationship between the oil prices and the different stock markets, the results reported in Table 3 show that many are the cases where a bi-directional feedback is present. Such are the cases of Australia, Belgium, Brazil, Canada, France, Germany, Greece, India, Korea, Mexico, Norway, Singapore, Spain, Turkey and the UK, where the oil prices are explained by the past movements of the stock market indices, and vice versa. By contrast, in Kuwait the direction of the causality runs only from the stock market to the oil prices, meaning that the lagged terms of the stock market may be statistically different from zero when estimating the oil prices. In the case of the Netherlands, Nigeria, Oman, Qatar, Russia, and the US, it can be said the oil prices can be used to predict the values of the stock market indices from those countries, most of them oil exporting countries. For Saudi Arabia and Kazakhstan, the links between the oil prices and the stock markets could not be determined due to the fact that there was not enough data to perform the test (only 37 observations for each stock market index). The remaining countries do not show any causality among the variables making them independent. In general, we don't seem to find a strong impact of the oil prices on the interest rates, neither of the interest rates on the oil prices in the short-run. Nonetheless, as regard the short-term interaction between the oil prices and the stock markets, many are the cases of bi-directional feedback, most of them in oil importing countries, few of them in oil exporting countries, but none of them in OPEC countries. Similar results were found by Lescaroux and Mignon (2008) who argued that there was no causality between oil prices and share prices in the OPEC countries, but a strong influence of oil price movements on share prices on the short-run for the oil exporting countries as well as for some oil importing countries. On the other hand, Jones and Kaul (1996), in their analysis of the reaction of international stock markets to oil price shocks, reported that oil prices Granger-precede stock returns for Canada, Japan and the US, but not for the UK. As regard the interest rates, Henriques and Sadorsky (2008) expressed that lagged interest rates have some statistically significant impact on current oil prices at the 5\% significance level, but the oil prices do not have a Granger causal impact on interest rates. 
As it was explained before, in order to study the long-run relationship among the variables, it was necessary to conduct Cointegration Tests and estimate VECMs. Since for simplicity and homogeneity among the countries it was assumed that all the series were integrated of the same order $(I(1))$, it was possible to proceed with the cointegration tests allowing us to detect the interactions between the variables and avoiding the problems of spurious regressions. In the case of the Johansen approach for multiple equations the null hypothesis based on the trace statistic is that the number of cointegrating vectors is equal to or less than $r$. Thus, if the first time the null hypothesis could not be rejected was when $\mathrm{r}$ was equal to or higher that one, then the country was considered to present cointegration among the series.

The results of the Johansen Cointegration Tests for the three variables are presented in Table 4. It is clear that most countries do not show cointegration among the variables, in other words the first time the null hypothesis could not be rejected was when the number of cointegrating vectors was still equal to zero. Therefore, the analysis stopped at this point and for these countries it was concluded that there are no long-run links among the series. By contrast, for the cases of Australia, China, India, Nigeria and Turkey the results suggested showed evidence of failure to reject the null hypothesis when the number of cointegrating vectors was equal to or higher than one, showing stationary cointegrating relationships. Moreover, Australia, China, India and Turkey have one cointegrating vector and the Model 2 was the one that suggested that the trace statistic was smaller than the 5\% critical value. Whereas for Nigeria, the non-rejection of the null hypothesis occurred in the Model 3 and when the number of cointegrating vectors were two. This latter country confirms the theory that when there are more than two variables in the model, it might be more than one cointegrating vector.

The final step was to estimate the VECM equations for the countries that presented cointegrating links, and check for the significance of the coefficients for each variable. For each country we first regressed the interest rates to the cointegrating equation (ECM) term(s) and the 12 lagged terms of the interest rates, oil prices and stock markets (all the variables in first differences). Then the oil prices were taken as the dependent variable and finally the stock markets were defined as the predicted variable. The results are shown in Tables 5, 6, 7, 8 and 9 .

In the case of Australia (see Table 5), the ECM term resulted significant at the $10 \%$ significance level for the interest rate and the stock market equations, indicating that both of them were adjusted with a lag. For the latter, the oil prices were also significant, suggesting that their changes will have an immediate positive impact on the Australian stock market. However, for the oil prices estimation, none of the variables rejected the null hypothesis $(\beta=0)$, meaning that there are neither short-run nor long-run effects on the oil price series when the series fluctuate.

Regarding China (see Table 6), only in the case of the stock market, all the redundant variables rejected the null hypothesis at the $10 \%$ significance level. Therefore, it seems that the disequilibrium in the Chinese stock market is adjusted within one month and that the interest rate and the oil prices have a negative short-run effect on the stock market. Whereas, for the interest rate and the oil prices the ECM terms and the independent variables were insignificant.

Turning to India (see Table 7), for the interest rate ECM specification none of the redundant variables rejected the null hypothesis of non-causality, suggesting neither short-run nor long-run effects on the interest rate from India. Meanwhile for the oil prices regression the ECM term and the stock market rejected the null hypothesis. This means that almost $37 \%$ of the discrepancy between the short-term and the long-term of the oil prices are corrected within a month and that the fluctuations in the stock market have a statistically significant positive impact on the oil prices in the short-run. Similarly, for the stock market estimation only the interest rate was not significant. In this case, it can be said that the disequilibrium in the stock market was corrected with a lag, and the oil prices have an immediate and negative influence on the stock market from India.

Regarding Turkey (see Table 8), all the redundant variables and the ECM term were significant in estimating the interest rate. This indicates that about $33 \%$ of the discrepancy between the long-term and the short-term interest rate are corrected within one month. Furthermore, changes in the oil prices and in the Turkish stock market affected the interest rate positively and negatively, respectively, in the short-run. Whereas for the oil prices and the stock market equations, only the stock market for the former and the interest rate for the latter can be said that cause the dependent variable in the short-term (for both cases the coefficients are negative).

Finally, the interest rate and the stock market from Nigeria (see Table 9) were not affected by the redundant variables, implying that neither there are short-run effects nor the series have the tendency to restore the equilibrium. On the other hand, in the case of the oil prices the ECM terms and the interest rate rejected the null hypothesis of non-causality. Meaning that first, the measure of the long-run disequilibrium is significant, and second, in the short-term the interest rate from Nigeria does cause the oil prices with a positive coefficient. 
Table 5. Vector error correction estimates and redundant variable tests for Australia

\begin{tabular}{|c|c|c|c|}
\hline Variables & dint_rate & doil_price & dstock_marktet \\
\hline Constant & -0.0434 & 0.0325 & 0.8241 \\
\hline Cointeq1 & -0.0324 & -0.0027 & -1.0181 \\
\hline dinterest rate(-1) & 0.2162 & 0.2310 & -3.5169 \\
\hline dinterest rate( -2$)$ & 0.0225 & 0.4976 & -1.5123 \\
\hline dinterest rate(-3) & 0.0683 & 0.6133 & 0.6634 \\
\hline dinterest rate(-4) & 0.0305 & -0.2462 & 1.7996 \\
\hline dinterest_rate(-5) & 0.0945 & -0.3163 & 2.7942 \\
\hline dinterest_rate(-6) & -0.0240 & -0.2744 & -5.3976 \\
\hline dinterest rate(-7) & 0.1254 & -0.5841 & -3.1178 \\
\hline dinterest rate(-8) & -0.1080 & 0.4369 & -0.0876 \\
\hline dinterest rate(-9) & 0.2852 & -0.5072 & 4.9472 \\
\hline dinterest rate $(-10)$ & -0.0865 & 0.5020 & 3.1978 \\
\hline dinterest rate(-11) & -0.1106 & 0.0871 & 0.0115 \\
\hline dinterest_rate(-12) & 0.1769 & 0.5282 & 4.6957 \\
\hline doil price(-1) & 0.0041 & 0.3148 & 0.8537 \\
\hline doil price $(-2)$ & 0.0069 & -0.2133 & -1.6314 \\
\hline doil price(-3) & 0.0054 & 0.1157 & -0.3136 \\
\hline doil price(-4) & 0.0078 & -0.1273 & 0.8677 \\
\hline doil price(-5) & 0.0301 & -0.2141 & -0.7950 \\
\hline doil price(-6) & 0.0130 & -0.0128 & 0.0923 \\
\hline doil price(-7) & 0.0017 & -0.0168 & -0.0680 \\
\hline doil price $(-8)$ & 0.0014 & 0.0506 & 0.0230 \\
\hline doil price(-9) & -0.0092 & -0.0752 & 0.8796 \\
\hline doil price(-10) & 0.0298 & 0.0657 & 0.9353 \\
\hline doil price(-11) & -0.0052 & 0.0844 & -1.6525 \\
\hline doil price(-12) & 0.0098 & 0.0665 & 2.1920 \\
\hline dstock market(-1) & 0.0006 & 0.0074 & -0.1805 \\
\hline dstock market(-2) & -0.0019 & 0.0249 & -0.0986 \\
\hline dstock market(-3) & 0.0007 & -0.0071 & -0.0562 \\
\hline dstock market(-4) & 0.0011 & 0.0113 & -0.1688 \\
\hline dstock market(-5) & 0.0005 & -0.0039 & -0.0544 \\
\hline dstock market(-6) & 0.0000 & 0.0079 & 0.0357 \\
\hline dstock market(-7) & -0.0014 & 0.0203 & 0.1559 \\
\hline dstock market(-8) & 0.0006 & 0.0112 & -0.1131 \\
\hline dstock market(-9) & 0.0013 & 0.0016 & 0.0465 \\
\hline dstock market(-10) & 0.0033 & 0.0163 & 0.1380 \\
\hline dstock market(-11) & 0.0037 & -0.0014 & 0.0112 \\
\hline dstock_market(-12) & 0.0009 & 0.0100 & 0.0001 \\
\hline Cointeq1 & $\begin{array}{r}12.8842 \\
(0.0005)\end{array}$ & $\begin{array}{c}0.0026 \\
(0.9596)\end{array}$ & $\begin{array}{c}4.7908 \\
(0.0305)\end{array}$ \\
\hline dinterest_rate(-1 to-12) & $\begin{array}{l}- \\
-\end{array}$ & $\begin{array}{l}0.9651 \\
(0.4857)\end{array}$ & $\begin{array}{c}0.7345 \\
(0.7155)\end{array}$ \\
\hline doil_price(-1 to-12) & $\begin{array}{c}0.6926 \\
(0.7560)\end{array}$ & $\begin{array}{l}- \\
-\end{array}$ & $\begin{array}{c}1.7067 \\
(0.0729)\end{array}$ \\
\hline \multirow[t]{2}{*}{ dstock_market(-1 to-12) } & 0.9879 & 1.4081 & - \\
\hline & $(0.4643)$ & $(0.1708)$ & - \\
\hline
\end{tabular}

Note: the numbers in bold denote that the series reject the null hypothesis at the $10 \%$ level of significance. The F-Critical value sused to compare the F- Statistics were calculated in EViews 6.12 were the number of lags included in the procedure. The numbers in parentheses are the p-values. 
Table 6. Vector error correction estimates and redundant variable tests for China

\begin{tabular}{|c|c|c|c|}
\hline Variables & dint_rate & doil_price & dstock_marktet \\
\hline Constant & -0.0082 & -0.2123 & 1.1511 \\
\hline dinterest_rate(-1) & -0.0928 & -0.4046 & -1.1516 \\
\hline dinterest_rate(-2) & -0.0439 & 0.3097 & 2.1421 \\
\hline dinterest_rate(-3) & -0.0374 & 0.9588 & 0.9948 \\
\hline dinterest_rate(-4) & 0.2184 & -0.0843 & -0.8477 \\
\hline dinterest_rate(-5) & 0.1630 & 0.9917 & 0.6752 \\
\hline dinterest_rate(-6) & 0.0772 & -0.0232 & -0.4182 \\
\hline dinterest_rate(-7) & -0.0953 & -1.1290 & -3.2671 \\
\hline dinterest_rate(-8) & -0.0646 & 0.5415 & 0.2977 \\
\hline dinterest_rate(-9) & 0.0385 & -0.1306 & -1.6666 \\
\hline dinterest_rate(-10) & -0.1526 & -0.6969 & -0.3202 \\
\hline dinterest_rate(-11) & 0.0936 & -0.5818 & 0.3950 \\
\hline dinterest_rate(-12) & 0.0503 & -1.8414 & -4.7383 \\
\hline doil_price(-1) & 0.0048 & 0.4155 & -0.0611 \\
\hline doil_price(-2) & 0.0069 & 0.1235 & -0.0165 \\
\hline doil_price(-3) & 0.0109 & -0.1173 & -0.2689 \\
\hline doil_price(-4) & 0.0056 & -0.0596 & -0.0968 \\
\hline doil_price(-5) & -0.0037 & -0.1628 & -0.1893 \\
\hline doil_price(-6) & -0.0006 & -0.2452 & -0.1146 \\
\hline doil_price(-7) & 0.0091 & 0.0999 & -0.1389 \\
\hline doil_price(-8) & -0.0048 & -0.0380 & -0.1114 \\
\hline doil_price(-9) & 0.0054 & -0.1636 & -0.2316 \\
\hline doil_price(-10) & 0.0013 & 0.1529 & -0.3285 \\
\hline doil_price(-11) & 0.0126 & 0.0899 & 0.0056 \\
\hline doil_price(-12) & -0.0065 & -0.1893 & -0.3939 \\
\hline dstock_market(-1) & 0.0038 & 0.0557 & 0.1631 \\
\hline dstock_market(-2) & -0.0011 & 0.0123 & 0.1961 \\
\hline dstock_market(-3) & -0.0012 & -0.0533 & -0.0521 \\
\hline dstock_market(-4) & 0.0107 & 0.0782 & -0.0200 \\
\hline dstock_market(-5) & 0.0061 & 0.0322 & 0.0671 \\
\hline dstock_market(-6) & 0.0022 & 0.0992 & -0.0003 \\
\hline dstock_market(-7) & -0.0045 & 0.0644 & 0.2204 \\
\hline dstock_market(-8) & 0.0027 & 0.0912 & 0.0507 \\
\hline dstock_market(-9) & -0.0005 & -0.0016 & 0.0526 \\
\hline dstock_market(-10) & -0.0039 & 0.0962 & 0.2597 \\
\hline dstock_market(-11) & -0.0021 & -0.0604 & -0.0326 \\
\hline dstock_market(-12) & 0.0033 & 0.0035 & -0.0210 \\
\hline Cointeq1 & $\begin{array}{c}0.3368 \\
(0.5626)\end{array}$ & $\begin{array}{c}1.2842 \\
(0.2590)\end{array}$ & $\begin{array}{l}21.7798 \\
(0.0000)\end{array}$ \\
\hline dinterest_rate(-1to-12) & - & $\begin{array}{c}0.7234 \\
(0.7267)\end{array}$ & $\begin{array}{c}2.5589 \\
(0.0043)\end{array}$ \\
\hline doil_price(-1 to-12) & $\begin{array}{c}1.1918 \\
(0.2945)\end{array}$ & - & $\begin{array}{c}1.9473 \\
(0.0336)\end{array}$ \\
\hline dstock_market(-1 to-12) & $\begin{array}{c}1.2861 \\
(0.2330)\end{array}$ & $\begin{array}{c}1.3439 \\
(0.2005)\end{array}$ & - \\
\hline
\end{tabular}

Note: the numbers in bold denote that the series reject the null hypothesis at the $10 \%$ level of significance. The F-Critical value sused to compare the F- Statistics were calculated in EViews 6.12 were the number of lags included in the procedure. The numbers in parentheses are the p-values. 
Table 7. Vector error correction estimates and redundant variable tests for India

\begin{tabular}{|c|c|c|c|}
\hline Variables & dint_rate & doil_price & dstock_market \\
\hline Constant & -0.0598 & -0.0097 & 4.4165 \\
\hline Cointeq1 & 0.0023 & -0.3696 & 1.8254 \\
\hline dinterest rate(-1) & 0.0323 & -0.1196 & -3.6999 \\
\hline dinterest $\operatorname{rate}(-2)$ & 0.0614 & 0.4060 & 11.3121 \\
\hline dinterest $\operatorname{rate}(-3)$ & -0.3674 & 1.6693 & -8.9631 \\
\hline dinterest rate(-4) & -0.1171 & 1.1689 & 5.9179 \\
\hline dinterest rate $(-5)$ & 0.0633 & 0.2394 & -0.3008 \\
\hline dinterest rate(-6) & -0.0503 & 1.1441 & -3.9665 \\
\hline dinterest rate(-7) & -0.1541 & 1.1474 & 3.2073 \\
\hline dinterest rate $(-8)$ & 0.0306 & 0.6678 & 5.9935 \\
\hline dinterest rate(-9) & -0.1073 & 0.4744 & -4.2716 \\
\hline dinterest rate $(-10)$ & 0.0558 & -0.0656 & -2.7757 \\
\hline dinterest rate(-11) & 0.1393 & 0.1288 & 3.6706 \\
\hline dinterest rate(-12) & -0.0476 & 0.8632 & -1.8767 \\
\hline doil price(-1) & -0.0030 & 0.2797 & 0.2072 \\
\hline doil price $(-2)$ & -0.0009 & 0.1575 & 0.4120 \\
\hline doil_price(-3) & -0.0001 & -0.0264 & -0.6505 \\
\hline doil_price(-4) & -0.0016 & 0.0343 & -0.8714 \\
\hline doil price $(-5)$ & 0.0042 & -0.0343 & -1.7978 \\
\hline doil_price(-6) & -0.0027 & -0.1351 & 0.3777 \\
\hline doil_price(-7) & 0.0002 & 0.1319 & -1.0587 \\
\hline doil price(-8) & 0.0030 & 0.0427 & -1.5127 \\
\hline doil price(-9) & -0.0060 & -0.0828 & -1.4564 \\
\hline doil price(-10) & -0.0011 & 0.1931 & -1.0431 \\
\hline doil price $(-11)$ & 0.0055 & 0.1310 & -0.4032 \\
\hline doil price(-12) & -0.0092 & -0.1086 & -3.4436 \\
\hline dstock market(-1) & -0.0007 & -0.0175 & 0.3193 \\
\hline dstock_market(-2) & 0.0000 & -0.0114 & -0.0222 \\
\hline dstock_market(-3) & -0.0002 & -0.0060 & 0.1241 \\
\hline dstock market(-4) & 0.0003 & 0.0133 & 0.1288 \\
\hline dstock market(-5) & -0.0002 & 0.0252 & 0.0609 \\
\hline dstock market(-6) & 0.0027 & 0.0535 & 0.0765 \\
\hline dstock market(-7) & 0.0005 & 0.0377 & 0.0882 \\
\hline dstock market(-8) & 0.0003 & 0.0323 & -0.2312 \\
\hline dstock market(-9) & 0.0009 & -0.0021 & 0.1292 \\
\hline dstock market(-10) & 0.0012 & 0.0030 & 0.0380 \\
\hline dstock market(-11) & 0.0006 & -0.0021 & 0.0756 \\
\hline dstock_market(-12) & 0.0001 & -0.0172 & 0.1459 \\
\hline Cointeq1 & $\begin{array}{c}0.0564 \\
(0.8127)\end{array}$ & $\begin{array}{r}10.6196 \\
(0.0014)\end{array}$ & $\begin{array}{c}5.7177 \\
(0.0181)\end{array}$ \\
\hline dinterest_rate(-1 to-12) & $\begin{array}{l}- \\
-\end{array}$ & $\begin{array}{l}0.5372 \\
(0.8874)\end{array}$ & $\begin{array}{c}0.6429 \\
(0.8025)\end{array}$ \\
\hline doil_price(-1to-12) & $\begin{array}{c}0.2130 \\
(0.9977)\end{array}$ & - & $\begin{array}{c}4.5642 \\
(0.0000)\end{array}$ \\
\hline dstock_market(-1to-12) & $\begin{array}{c}0.5354 \\
(0.8887) \\
\end{array}$ & $\begin{array}{c}3.2492 \\
(0.0004) \\
\end{array}$ & $\begin{array}{l}- \\
- \\
\end{array}$ \\
\hline
\end{tabular}

Note: the numbers in bold denote that the series reject the null hypothesis at the $10 \%$ level of significance. The F-Critical value sused to compare the F- Statistics were calculated in EViews 6.12 were the number of lags included in the procedure. The numbers in parentheses are the p-values. 
Table 8. Vector error correction estimates and redundant variable tests for Turkey

\begin{tabular}{|c|c|c|c|}
\hline Variable & dint_rate & doil_price & dstock_market \\
\hline Constant & -1.0658 & 0.2207 & 1.4644 \\
\hline Cointeq1 & -0.3252 & -0.0167 & 0.2109 \\
\hline dinterest_rate(-1) & -0.2425 & -0.0119 & -0.6186 \\
\hline dinterest_rate(-2) & -0.0587 & 0.0034 & -0.4857 \\
\hline dinterest_rate(-3) & -0.2958 & 0.0193 & 0.0249 \\
\hline dinterest_rate(-4) & -0.3280 & -0.0073 & -0.1460 \\
\hline dinterest_rate(-5) & 0.0200 & -0.0193 & -0.5608 \\
\hline dinterest_rate(-6) & -0.4036 & -0.0003 & 0.1697 \\
\hline dinterest_rate(-7) & -0.2017 & -0.0098 & -0.4384 \\
\hline dinterest_rate(-8) & -0.2015 & -0.0269 & -0.5285 \\
\hline dinterest_rate(-9) & -0.0931 & -0.0075 & 0.0503 \\
\hline dinterest_rate(-10) & -0.1286 & -0.0185 & -0.0156 \\
\hline dinterest_rate(-11) & -0.0188 & -0.0208 & -0.2576 \\
\hline dinterest_rate(-12) & -0.0666 & -0.0005 & 0.2378 \\
\hline doil_price(-1) & 1.4578 & 0.2482 & -0.0880 \\
\hline doil_price(-2) & 0.5764 & -0.2524 & -1.9095 \\
\hline doil_price(-3) & -0.2182 & 0.0498 & -0.4996 \\
\hline doil_price(-4) & 1.0105 & -0.2248 & -0.2386 \\
\hline doil_price(-5) & 1.1054 & 0.2007 & 1.0274 \\
\hline doil_price(-6) & 1.1166 & -0.3236 & 0.7243 \\
\hline doil_price(-7) & -0.3671 & 0.1504 & 1.8262 \\
\hline doil_price(-8) & 0.7472 & -0.1628 & -0.1849 \\
\hline doil_price(-9) & 0.9052 & -0.0147 & 2.1962 \\
\hline doil_price(-10) & 0.0629 & 0.1900 & -1.6890 \\
\hline doil_price(-11) & -1.1236 & 0.1588 & 1.0689 \\
\hline doil_price(-12) & 1.2730 & -0.1121 & -1.5098 \\
\hline dstock_market(-1) & -0.1639 & -0.0053 & 0.0400 \\
\hline dstock_market(-2) & -0.0332 & 0.0011 & 0.0061 \\
\hline dstock_market(-3) & -0.1937 & 0.0050 & -0.0417 \\
\hline dstock_market(-4) & -0.1014 & -0.0096 & 0.0683 \\
\hline dstock_market(-5) & -0.0382 & -0.0013 & 0.0063 \\
\hline dstock_market(-6) & -0.0865 & 0.0135 & 0.1544 \\
\hline dstock_market(-7) & -0.2222 & 0.0140 & 0.0762 \\
\hline dstock_market(-8) & -0.0802 & -0.0028 & -0.0445 \\
\hline dstock_market(-9) & -0.0464 & -0.0002 & 0.0312 \\
\hline dstock_market(-10) & -0.0743 & 0.0024 & 0.0408 \\
\hline dstock_market(-11) & -0.1258 & -0.0208 & -0.0915 \\
\hline dstock_market(-12) & -0.0290 & -0.0024 & 0.1075 \\
\hline \multirow[t]{2}{*}{ Cointeq 1} & 28.0071 & 1.9520 & 1.5150 \\
\hline & $(0.0000)$ & $(0.1654)$ & $(0.2212)$ \\
\hline \multirow[t]{2}{*}{ dinterest_rate(-1 to-12) } & - & 0.7313 & 1.9158 \\
\hline & - & $(0.7179)$ & $(0.0408)$ \\
\hline \multirow[t]{2}{*}{ doil_price(-1to-12) } & 2.0572 & - & 0.9020 \\
\hline & $(0.0267)$ & - & $(0.5477)$ \\
\hline \multirow[t]{2}{*}{ dstock_market(-1 to -12) } & 5.5254 & 2.0807 & - \\
\hline & $(0.0000)$ & $(0.0245)$ & - \\
\hline
\end{tabular}

Note: the numbers in bold denote that the series reject the null hypothesis at the $10 \%$ level of significance. The F-Critical value sused to compare the F- Statistics were calculated in EViews 6.12 were the number of lags included in the procedure. The numbers in parentheses are the p-values. 
Table 9. Vector error correction estimates and redundant variable tests for Nigeria

\begin{tabular}{|c|c|c|c|}
\hline Variable & dint_rate & doil_price & dstock_market \\
\hline Constant & -1.4333 & 0.8836 & -7.0565 \\
\hline Cointeq1 & -0.3157 & -2.1726 & -9.3996 \\
\hline Cointeq2 & -0.0436 & -0.7893 & -1.2676 \\
\hline dinterest_rate(-1) & 0.4265 & 1.9901 & 6.6985 \\
\hline dinterest_rate $(-2)$ & 0.3572 & 1.9097 & 12.5172 \\
\hline dinterest_rate $(-3)$ & -0.1721 & 1.3761 & 4.8653 \\
\hline dinterest_rate(-4) & 0.0519 & 1.5550 & -0.2900 \\
\hline dinterest_rate $(-5)$ & 0.1141 & 2.0842 & -3.9992 \\
\hline dinterest_rate(-6) & -0.0566 & 1.3836 & 7.3808 \\
\hline dinterest_rate(-7) & 0.1230 & 0.6680 & 7.9451 \\
\hline dinterest_rate $(-8)$ & -0.0305 & 2.0148 & 8.0803 \\
\hline dinterest_rate(-9) & 0.0495 & 1.3172 & -2.1742 \\
\hline dinterest_rate(-10) & -0.1406 & -0.0684 & 7.1969 \\
\hline dinterest_rate(-11) & 0.0712 & 1.3768 & -1.7843 \\
\hline dinterest_rate(-12) & -0.0240 & -0.1751 & 4.0620 \\
\hline doil_price(-1) & -0.0081 & 0.8417 & 2.0290 \\
\hline doil_price(-2) & 0.0433 & 0.7574 & -0.0076 \\
\hline doil_price(-3) & 0.0556 & 0.2829 & 3.6838 \\
\hline doil_price(-4) & 0.0421 & 0.3302 & -0.8663 \\
\hline doil_price(-5) & 0.1129 & 0.1017 & -0.5381 \\
\hline doil_price(-6) & 0.0807 & -0.0457 & -3.9884 \\
\hline doil_price(-7) & -0.0295 & 0.4994 & -0.4589 \\
\hline doil_price(-8) & 0.1019 & 0.5661 & 0.1961 \\
\hline doil_price(-9) & 0.0885 & 0.2103 & 1.8336 \\
\hline doil_price(-10) & 0.0194 & 0.7746 & 1.8780 \\
\hline doil_price(-11) & 0.0609 & 0.6533 & -0.7568 \\
\hline doil_price(-12) & 0.0376 & 0.4624 & 0.5108 \\
\hline dstock_market(-1) & -0.0039 & -0.0321 & 0.0326 \\
\hline dstock_market(-2) & 0.0055 & -0.0031 & -0.0977 \\
\hline dstock_market(-3) & 0.0052 & -0.0140 & 0.4083 \\
\hline dstock_market(-4) & 0.0059 & -0.0284 & -0.0921 \\
\hline dstock_market(-5) & 0.0020 & -0.0062 & 0.2682 \\
\hline dstock_market(-6) & 0.0116 & -0.0431 & -0.1780 \\
\hline dstock_market(-7) & 0.0047 & -0.0467 & 0.2750 \\
\hline dstock_market(-8) & 0.0031 & -0.0273 & -0.0549 \\
\hline dstock_market(-9) & 0.0054 & -0.0578 & 0.5095 \\
\hline dstock_market(-10) & 0.0074 & -0.0580 & 0.0059 \\
\hline dstock_market(-11) & 0.0003 & -0.0161 & 0.3554 \\
\hline dstock_market(-12) & 0.0019 & -0.0166 & -0.0866 \\
\hline \multirow[t]{2}{*}{ Cointeq1 } & 1.7321 & 11.4704 & 2.4938 \\
\hline & $(0.1992)$ & $(0.0022)$ & $(0.1259)$ \\
\hline \multirow[t]{2}{*}{ Cointeq2 } & 0.3592 & 16.4655 & 0.4932 \\
\hline & $(0.5540)$ & $(0.0004)$ & $(0.4885)$ \\
\hline \multirow[t]{2}{*}{ dinterest_rate(-1 to-12) } & - & 2.2934 & 1.3214 \\
\hline & - & $(0.0358)$ & $(0.2634)$ \\
\hline \multirow[t]{2}{*}{ doil_price(-1to-12) } & 0.5971 & - & 1.5924 \\
\hline & $(0.8253)$ & - & $(0.1531)$ \\
\hline \multirow[t]{2}{*}{ dstock_market(-1 to-12) } & 0.2588 & 1.4048 & - \\
\hline & $(0.9914)$ & $(0.2235)$ & - \\
\hline
\end{tabular}

Note: the numbers in bold denote that the series reject the null hypothesis at the $10 \%$ level of significance. The F-Critical value sused to compare the F- Statistics were calculated in EViews 6.12 were the number of lags included in the procedure. The numbers in parentheses are the p-values. 


\section{Summary and Conclusions}

The aim of this study was to analyse the influence of the oil price movements on the stock markets and the interest rates from 31 countries, including oil importing, oil exporting countries (including countries members of OPEC). To this end, the first step was to define the order of integration of the data series involved in the process by conducting the ADF test for unit roots. The results showed that, as it is common for economic variables, the series were integrated of order one $(I(1))$ for most countries. Then pairwise Granger Causality tests were conducted with the stationary series, in order to assess the degree of interaction between the variables. From the results we could conclude that the relationship between the oil prices and the interest rates seems very weak in the short-runand just few countries in the sample (6 out of the 31 countries) presented an interaction among these variables. The past values of the oil prices might be used to predict the interest rates only from three countries, namely the Netherlands, the UK and the US (all of them oil importing countries). Similarly, only the interest rates from Germany (oil importing country), Oman and Saudi Arabia (oil exporting countries) can be said that affect the performance of the oil prices. On the other hand, the short-term interaction between the oil prices and the stock markets seems to be much stronger with bi-directional feedbacks present in 15 out of the 31 countries in the sample (almost half of the countries). It has to be mentioned that most of these countries (11) are oil importing countries. Furthermore, six were the cases where only the oil prices were proved to cause the stock markets (four of these countries are oil exporters) and in one case (oil exporter - OPEC member country) the causality runs from the stock market to the oil prices. Overall, just a few countries ( 9 out of the $31-$ less than one third of the countries) demonstrate to have independency among the variables.

It is interesting to note that, first of all, more are the cases where the oil prices can predict the financial variables than those where the financial variables can cause the oil prices. Secondly, fluctuations in the oil prices seem to affect more oil importing countries than oil exporting countries. And thirdly, the oil prices are affected by more oil importing financial variables, than by oil exporting financial series. In turn, Lescaroux and Mignon (2008) also reported differences in the influence of oil prices on share prices in the short-run, indicating that the impact was strong for oil exporting and oil importing countries but insignificant for the OPEC countries.

In order to study the long-run relationship between the series, we run the Johansen Cointegration tests. Most of the countries did not present any long-term link among the financial variables and the oil prices with the exception of Australia, China, India, and Turkey (4 out of the 18 oil importing countries in the sample), and Nigeria (the only one from the 13 oil exporting countries in the sample that is also an OPEC country). Finally, from the VECM estimations it is worth noting that in the cases of Australia and China, the movements in the financial markets do not affect the behaviour of the oil prices in the short-run, nor the ECM term seems to adjust the discrepancies between the short-term and the long-term. Furthermore, in Turkey just the stock market has an immediate impact on the oil prices. Only in India the disequilibrium in the oil prices were corrected within one month and the stock markets can be used for the prediction of oil prices' performance in the short-run.

Regarding the interest rates, China and India did not show any significance in the variables implying that there are no short-run neither long-run effects on the interest rates from those countries. In the case of Australia, only ECM term was found significant suggesting the correction of the discrepancy. Nevertheless, the oil prices and the stock market seem to affect the interest rate fluctuations from Turkey and the disequilibrium seems to be adjusted with a lag. On the other hand, Australia, China, India and Turkey showed significance in some of the variables included in the stock markets equations. For instance, the stock markets from Australia, China and India are adjusted within one month. With the exception of Turkey, the oil prices have an important short-term impact on the stock markets from the countries mentioned before. Moreover, the Chinese and the Turkish interest rates have an immediate influence on the stock market indices from those countries. Interestingly, Nigeria was the only oil exporting country that showed cointegrating links between the series. At the same time it was the only country, from the entire set, that presented two cointegrating vectors. In addition, the African nation, in contrast to the previous cases, just reported significance in the oil prices estimation, where the disequilibrium is measured by the ECM terms and the interest rate influenced the behaviour of the dependent variable in a positive way.

We can conclude that the impact of the financial variables on the oil prices is weaker than the influence the oil prices have on the financial series, especially on the stock markets. Only in the case of Nigeria the interest rate affects the oil price movements, whereas the stock markets from Turkey as well as from India have an impact on the oil prices, indicating that the link between the stock markets and the oil prices is stronger than the one existing between the interest rates and the oil prices. Furthermore, the impact of the oil prices on the stock markets was positive in Australia (developed country) but negative in China and India (developing countries). The influence of the interest rates on the stock markets was always negative whereas the influence of the stock 
markets on the oil prices was positive for India but negative for Turkey.

Summarising, we can state that according to our results, the oil prices interact with the stock markets in a stronger manner than with the interest rates in the short as well as in the long-run. Furthermore, the significance of this impact is higher on oil importing countries than on oil exporting countries. Finally, the fluctuations in oil prices might present different effects among different countries and a possible explanation for this can be the degree of development of the countries.

\section{References}

Aloui, C., \& Jammazi, R. (2009). The effects of crude oil shocks on stockmarket shifts behaviour: A regime switching approach. Energy Economics, 31, 789-799. http://dx.doi.org/10.1016/j.eneco.2009.03.009

Apergis, N., \& Miller, S. M. (2009). Do structural oil-market shocks affect stock prices? Energy Economics, 31, 569-575. http://dx.doi.org/10.1016/j.eneco.2009.03.001

Asteriou, D., \& Hall, S. G. (2007). Applied econometrics: A modern approach. New York: Palgrave MacMillan.

Bjømland, H. C. (2008). Oil price shocks and stock market booms in an oil exporting country. Scottish Journal of Political Economy, 56, 232-254. http://dx.doi.org/10.1111/j.1467-9485.2009.00482.x

Boyer, M. M., \& Filion, D. (2007). Common and fundamental factors in stock returns of Canadian oil and gas companies. Energy Economics, 29, 428-453. http://dx.doi.org/10.1016/j.eneco.2009.03.009

Cameron, K., \& Schnusenberg, O. (2009). Oil prices, SUVs, and Iraq: An investigation of automobile manufacturer oil price sensitivity. Energy Economics, 31, 375-381. http://dx.doi.org/10.1016/j.eneco.2008.12.003

Cobo-Reyes, R., \& Pérez Quirós, G. (2005). The effect of oil price on industrial production and on stock returns. The Papers from Department of Economic Theory and Economic History of the University of Granada No. 05/18. Retrieved from http://www.ugr.es/ teoriahe/RePEc/gra/wpaper/thepapers05_18.pdf

Cong, R. G., Wei, Y. M., Jiao, J. L., \& Fan, Y. (2008). Relationships between oil price shocks and stock market: An empirical analysis from China. Energy Policy, 36, 3544-3553. http://dx.doi.org/10.1016/j.enpol.2008.06.006

Dickey, D. A., \& Fuller, W. A. (1981). Likelihood ratio statistics for autoregressive time series with a unit root. Econometrica, 49, 1057-1072. http://www.jstor.org/stable/1912517

Driesprong, G., Jacobsen, B., \& Maat, B. (2008). Striking oil: Another puzzle? Journal of Financial Economics, 89, 307-327. http://dx.doi.org/10.1016/j.jfineco.2007.07.008

Faff, R. W., \& Brailsford, T. J. (1999). Oil price risk and the Australian stock market. Journal of Energy Finance and Development, 4, 69-87. http://dx.doi.org/10.1016/S1085-7443(99)00005-8

Fuller, W. A. (1976). Introduction to statistical time series. New York: John Wiley. Retrieved from http://onlinelibrary.wiley.com/doi/10.1002/9780470316917.fmatter/pdf

Garefalakis, A., Dimitras, A., Koemtzopoulos, D., \& Spinthiropoulos, K. (2011). Determinant Factors of Hong Kong Stock Market. International Research Journal of Finance and Economics, 62, 50-60.

Granger, C. W. J. (1969). Investigating causal relations by econometric models and cross-spectral methods. Econometrica, 37, 424-438. Retrieved from http://www.jstor.org/stable/1912791

Guidi, M. G. D., Russell, A., \& Tarbert, H. (2006). The effect of OPEC policy decisions on oil and stock prices. OPEC Review, 30, 1-18.

Hamilton, J. D. (1983). Oil and the macroeconomy since World War II. Journal of Political Economy, 91, 228-248. Retrieved from http://www.jstor.org/stable/1832055?origin=JSTOR-pdf

Hammoudeh, S., \& Li, H. (2005). Oil sensitivity and systematic risk in oil-sensitive stock indices. Journal of Economics and Business, 57, 1-21. http://dx.doi.org/10.1016/j.jeconbus.2004.08.002

Hammoudeh, S., \& Aleisa, E. (2004). Dynamic relationships among GCC stock markets and NYMEX oil futures. Contemporary Economic Policy, 22, 250-269.

Hammoudeh, S., Dibooglu, S., \& Aleisa, E. (2004). Relationships among U.S. oil prices and oil industry equity indices. International Review of Economics and Finance, 13, 427-453. http://dx.doi.org/10.1016/S1059-0560(03)00011-X

Hayo, B., \& Kutan, A. M. (2005). The impact of news, oil prices, and global market developments on Russian 
financial markets. Economics of Transition, 13, 373-393.

Henriques, I., \& Sadorsky, P. (2008). Oil prices and the stock prices of alternative energy companies. Energy Economics, 30, 998-1010. http://dx.doi.org/10.1016/j.eneco.2007.11.001

Hondroyiannis, G., \& Papapetrou, E. (2001). Macroeconomic influences on the stock market. Journal of Economics and Finance, 25, 33-49.

Huang, B., Hwang, M. J., \& Peng, H. (2005). The asymmetry of the impact of oil price shocks on economic activities: An application of the multivariate threshold model. Energy Economics, 27, 455-476. http://dx.doi.org/10.1016/j.eneco.2005.03.001

Huang, R. D., Masulis, R. W., \& Stoll, H. R. (1996). Energy shocks and financial markets. The Journal of Futures Markets, 16, 1-27.

Huang, Y., \& Guo, F. (2008). Macro shocks and the Japanese stock market. Applied Financial Economics, 18, $1391-1400$.

Johansen, S. (1988). Statistical analysis of cointegration vectors. Journal of Economics Dynamics and Control, 12, 231-254. http://dx.doi.org/10.1016/0165-1889(88)90041-3

Jones, C. M., \& Kaul, G. (1996). Oil and the stock markets. The Journal of Finance, 51, 463-491. http://dx.doi.org/10.1111/j.1540-6261.1996.tb02691.x

Lescaroux, F., \& Mignon, V. (2008). On the influence of oil prices on economic activity and other macroeconomic and financial variables. OPEC Energy Review, 32(4), 343-380.

Maghyereh, A. (2004). Oil price shocks and emerging stock markets: A generalized VAR approach. International Journal of Applied Econometrics and Quantitative Studies, 1, 27-40. Retrieved from http://www.usc.es/economet/reviews/ijaeqs122.pdf

Malik, F., \& Hammoudeh, S. (2007). Shock and volatility transmission in the oil, US and Gulf equity markets. International Review of Economics and Finance, 16, 357-368. http://dx.doi.org/10.1016/j.iref.2005.05.005

Miller, J. I., \& Ratti, R. A. (2009). Crude oil and stock markets: Stability, instability, and bubbles. Energy Economics, 31, 559-568. http://dx.doi.org/10.1016/j.eneco.2009.01.009

Mork, K. A. (1989). Oil and the macroeconomy when prices go up and down: an extension of Hamilton's results. Journal of Political Economy, 97, 740-744. http://www.jstor.org/stable/1830464

Nandha, M., \& Faff, R. (2008). Does oil move equity prices? A global view. Energy Economics, 30, 986-997. http://dx.doi.org/10.1016/j.eneco.2009.01.009

Odusami, B. O. (2009). Crude oil shocks and stock market returns. Applied Financial Economics, 19, 291-303.

Onour, I. A. (2007). Impact of oil price volatility on Gulf Cooperation Council stock markets return. OPEC Review, 31, 171-189.

Papapetrou, E. (2001). Oil price shocks, stock market, economic activity and employment in Greece. Energy Economics, 23, 511-532. http://dx.doi.org/10.1016/j.eneco.2009.01.009

Park, J., \& Ratti, R. A. (2008). Oil price shocks and stock markets in the US and 13 European countries. Energy Economics, 30, 2587-2608. http://dx.doi.org/10.1016/j.eneco.2008.04.003

Pollet, J. M. (2005). Predicting asset returns with expected oil price changes. Retrieved form http://dx.doi.org/10.2139/ssrn.722201.

Sadorsky, P. (1999). Oil price shocks and stock market activity. Energy Economics, 21, 449-469. http://dx.doi.org/10.1016/S0140-9883(99)00020-1

Sadorsky, P. (2001). Risk factors in stock returns of Canadian oil and gas companies. Energy Economics, 23, 17-28. http://dx.doi.org/10.1016/S0140-9883(00)00072-4

Sawyer, K. R., \& Nandha, M. (2006). How oil moves stock prices? University of Melbourne Working Paper. http://dx.doi.org/10.2139/ssrn.910427

Sims, C. A. (1980). Macroeconomics and reality. Econometrica, 48, 1-48. http://www.jstor.org/stable/1912017 


\section{Copyrights}

Copyright for this article is retained by the author(s), with first publication rights granted to the journal.

This is an open-access article distributed under the terms and conditions of the Creative Commons Attribution license (http://creativecommons.org/licenses/by/3.0/). 